\title{
Flavonoids from Chiococca braquiata (Rubiaceae)
}

\author{
Marcia N. Lopes ${ }^{a}$, André C. de Oliveira ${ }^{a}$, Maria Cláudia M. Young ${ }^{b}$ and Vanderlan da S. Bolzani ${ }^{*}, a$ \\ ${ }^{a}$ Instituto de Química, Universidade Estadual Paulista, CP 355, 14801-970 Araraquara - SP, Brazil \\ ${ }^{b}$ Seção de Fisiologia e Bioquímica de Plantas, Instituto de Botânica, CP 4005, 10051 São Paulo - SP, Brazil
}

\begin{abstract}
Um flavonol inédito, 4'-metoxikaempferol-7-(acetiloxi)-3,5-O- $\alpha$-L-ramnosídeo (1), três flavonóides conhecidos, apigenina, 7-O-metoxiquercetrina e quercetrina e quatro triterpenos, $\alpha$ amirina, $\beta$-amirina, ácido oleanólico e ácido ursólico foram isolados das folhas de Chiococca braquiata. As estruturas dessas substâncias foram elucidadas com base em seus dados espectroscópicos.
\end{abstract}

A new flavonol 4'-methoxykaempferol-7-(acetyloxy)-3,5- $O-\alpha$-L-rhamnoside (1), was isolated from the leaves of Chiococca braquiata, along with three known flavonoids apigenin, 7-Omethoxyquercetrin and quercetrin and four triterpenes $\alpha$-amirin, $\beta$-amirin, ursolic and oleanolic acids . Their structures were established on the basis of spectroscopic methods.

Keywords: Chiococca braquiata, Rubiaceae, flavonoids

\section{Introduction}

The genus Chiococca (Rubiaceae) with 22 species is endemic of the American Continent, and occurs from North America to Brazil. Several Chiococca species have been traditionally used in these regions for the treatment of numerous human ailments including inflammation, antivirus, anti-edema and as aphrodisiac. ${ }^{1}$ Other plants belonging to the Rubiaceae family have yielded a number of interesting biologically active compounds, ${ }^{2,3}$ including seco-iridoids with mild DNA-activity isolated from Chiococca alba. ${ }^{4}$ C. braquiata, however, has not been subjected to phytochemical analysis or assayed for any biological activity. In an ongoing quest to identify biologically active compounds from the Brazilian Rubiaceae plant species, antifungal evaluation using Cladosporium sphaerospermum and C. cladosporioides was performed on $\mathrm{CH}_{2} \mathrm{Cl}_{2}-\mathrm{MeOH}(2: 1, \mathrm{v} / \mathrm{v})$ extract from $C$. braquiata leaves, which exhibited strong antifungal activity. Bioassay-guided fractionation of the bioactive extract led to the isolation of the inactive flavonoids 4'methoxykaempferol-7-(acetyloxy)-3,5-O- $\alpha$-L-rhamnoside (1), apigenin, 7-O-methoxyquercetrin and quercetrin. The triterpenes $\alpha$-amirin, $\beta$-amirin, ursolic and oleanolic acids

\footnotetext{
* e-mail: bolzaniv@iq.unesp.br
}

were also isolated. The structure of the new derivative $\mathbf{1}$ and the known compounds were elucidated by spectroscopic methods, mainly 2D NMR and MS.

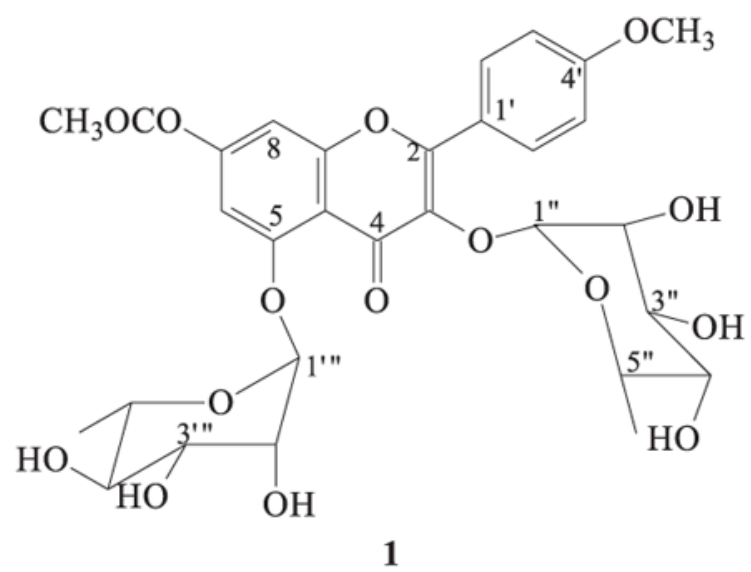

\section{Experimental}

\section{General procedures}

For column chromatography silica gel 60 (Merck 230400 mesh) and Sephadex LH-20 were used. TLC analysis carried out on silica gel $60 \mathrm{~F}_{254}$. IR spectrum was recorded on a Nicolet Spectrometer. UV spectra were recorded on a Perkin-Elmer UV/Vis Spectrometer Lambda 14P. The ESMS spectra were obtained on a VG Platform II Spectrometer. NMR spectra were recorded in DMSO- $\mathrm{d}_{6}$ or $\mathrm{CDCl}_{3}$ on a 
Varian Unit 500 instrument at $500 \mathrm{MHz}$ for ${ }^{1} \mathrm{H}$ and 125 $\mathrm{MHz}$ for ${ }^{13} \mathrm{C}$, using TMS as internal standard. The DEPT experiments were performed using polarization transfer pulses of 90 and $135^{\circ}$.

\section{Plant material}

Leaves of Chiococca braquiata Ruiz \& Pav. (now Chiococca alba (L.) Hitchc.) were collected around Lagoa do Abaeté, BA, Brazil and identified in the Botanical Institute, SMA, SP. A voucher no. 1934 specimen has been deposited in the herbarium Maria Eneida P. K. Fidalgo, SP, Brazil.

\section{Bioassay}

The antifungal activity against $C$. cladosporioides was performed using direct bioautography with $10 \mu \mathrm{L}$ of the solutions of crude extracts and pure compounds, which were prepared in different concentrations ranging from 300 to $10 \mu \mathrm{g}$ respectively, as described elsewhere. ${ }^{5}$

\section{Extraction and isolation of compounds}

Air-dried powdered leaves $(2.0 \mathrm{~kg})$ were extracted with $\mathrm{CH}_{2} \mathrm{Cl}_{2}-\mathrm{MeOH}(2: 1)$ at room temperature. The $\mathrm{CH}_{2} \mathrm{Cl}_{2}-$ $\mathrm{MeOH}$ extract was evaporated in vacuum to give a crude extract (120 g), which was partitioned into equal volumes of $\mathrm{MeO}-\mathrm{H}_{2} \mathrm{O}(80 \%)$ and hexane $(3 \mathrm{x})$. The hydromethanolic extract was concentrated to $60 \%$ and was subsequently extracted using $\mathrm{CHCl}_{3}(3 \mathrm{x})$ and EtOAc $(3 \mathrm{x})$. These were evaporated to give a hexane phase $(5 \mathrm{~g})$, a chloroform phase (12 g), an ethyl acetate phase (4.7 g) and a hydromethanolic phase (42 g).

The ethyl acetate phase was applied to a column of Sephadex LH-20 (30 g) eluted with $\mathrm{MeOH}-\mathrm{H}_{2} \mathrm{O}$ with increasing polarity to give 17 fractions. Fraction $8(123 \mathrm{mg})$ was applied again to a column of Sephadex LH-20 (5 g) eluted with $\mathrm{MeOH}$ to give 6 fractions. The sub-fractions 8.2 and 8.3 yielded mixture of triterpenes $\alpha$-amirin and $\beta$ amirin (39 mg) and ursolic and oleanolic acids (64 mg), respectively. Fractions 11 and 12 were combined (176 mg) and further purified by reverse phase preparative thin-layer chromatography in $\mathrm{MeOH}-\mathrm{H}_{2} \mathrm{O}(8.5: 1.5)$ leading to the isolation of 4'-methoxykaempferol-7-(acetyloxy)-3,5-O$\alpha$-L-rhamnoside (1; $21 \mathrm{mg}$ ). Fraction 13 (460 mg) was applied to a silica gel column (230-400 mesh) eluted with ethyl acetate containing increasing concentration of methanol (up to $100 \%$ ) to give apigenin $(2 ; 174 \mathrm{mg}$ ). Fraction 14/15 (111 mg) was applied to a column of Sephadex LH-20 (2 g) eluted with $\mathrm{MeOH}$ to give 7-O- methoxyquercetrin (3; $60 \mathrm{mg})$. Fractions 16/17 (175 mg), after recristalization in acetone, gave quercetrin (4; $165 \mathrm{mg})$.

4'-Methoxykaempferol-7-(acetyloxy)-3,5-O-a-Lrhamnoside (1). Colorless powder; IR (film) $v_{\max } / \mathrm{cm}^{-1}$ : 1695, 1688, 1600, 1443, 1213, 1060; ES-MS m/z (rel. int.) $[\mathrm{M}+\mathrm{Na}]^{+} 657$ (6.5), 634 (4), 363 (98), 317 (100), 170 (56), 147 (25); UV MeOH $\lambda_{\text {max }} / \mathrm{nm}: 341,259 ;{ }^{1} \mathrm{H}$ and ${ }^{13} \mathrm{C}$ NMR data see Table 1.

Apigenin (2). Colorless gum, identified by comparison (UV, ${ }^{1} \mathrm{H}$ and ${ }^{13} \mathrm{C} \mathrm{NMR}$ ) with literature data. ${ }^{6}$

7-O-Methoxyquercetrin (3). Colorless gum, identified by comparison (UV, ${ }^{1} \mathrm{H}$ and $\left.{ }^{13} \mathrm{C} \mathrm{NMR}\right)$ with literature data. ${ }^{7}$

Quercetrin (4). Colorless needles, mp $188-190^{\circ} \mathrm{C}$ (MeOH); identified by comparison (UV, ${ }^{1} \mathrm{H}$ and $\left.{ }^{13} \mathrm{C} \mathrm{NMR}\right)$ with literature data. ${ }^{8}$

Table 1. NMR spectral data of flavonol 1

\begin{tabular}{|c|c|c|c|}
\hline Position & $\delta_{\mathrm{H}}^{\mathrm{a}}$ & $\delta_{\mathrm{C}}^{\mathrm{b}}$ & $\mathrm{HMBC}^{\mathrm{a}}(\mathrm{H})$ \\
\hline 2 & - & $156.5 \mathrm{~s}$ & $2^{\prime}, 6^{‘}$ \\
\hline 3 & - & $134.2 \mathrm{~s}$ & $1 “$ \\
\hline 4 & - & $177.6 \mathrm{~s}$ & - \\
\hline 5 & - & $161.7 \mathrm{~s}$ & $6,1^{\prime \prime}$ \\
\hline 6 & $6.63(\mathrm{~d}, J 1.25)$ & $98.0 \mathrm{~d}$ & 6,8 \\
\hline 7 & - & $165.1 \mathrm{~s}$ & 6,8 \\
\hline 8 & $6.32(\mathrm{~d}, J 1.25)$ & $92.0 \mathrm{~d}$ & 6 \\
\hline 9 & - & $157.6 \mathrm{~s}$ & 8 \\
\hline 10 & - & $105.0 \mathrm{~s}$ & 6 \\
\hline 1 ' & - & $119.3 \mathrm{~s}$ & $3 \% / 5$ \\
\hline 2'-6’ & $7.75(\mathrm{~d}, J 8.0)$ & $130.5 \mathrm{~d}$ & $3 ' / 5$ \\
\hline $3^{\prime}-5^{\prime}$ & $6.89(\mathrm{~d}, J 8.0)$ & $115.8 \mathrm{~d}$ & $5^{\prime} / 6^{\prime}$ \\
\hline 4 & - & $161.7 \mathrm{~s}$ & $2^{\prime} / 6^{\prime}, \mathrm{OC}_{3}$ \\
\hline $1 ", 1 "$, & $5.30($ br s) & $101.8 \mathrm{~d}$ & $2 " / 2 "{ }^{\prime \prime} 3 / 3 "$ \\
\hline $2 ", 2 "$, & 3.92 (br dd, $J 9.0,11.0$ ) & $72.5 \mathrm{~d}$ & - \\
\hline 3"', 3"' & $3.48(\mathrm{dd}, J$ 9.0, 10.8) & $72.6 \mathrm{~d}$ & - \\
\hline 4", 4"” & $3.08 \mathrm{~m}$ & $74.4 \mathrm{~d}$ & - \\
\hline $5 ", 5 "$ & $3.28(\mathrm{~m})$ & $71.1 \mathrm{~d}$ & - \\
\hline 6"'6"' & $0.87(\mathrm{~d}, J 6.5)$ & $17.5 ; 18.5 \mathrm{q}$ & - \\
\hline $\mathrm{OMe}$ & $3.79(\mathrm{~s})$ & $56.0 \mathrm{q}$ & - \\
\hline $\mathrm{C}=\mathrm{O}$ & - & $174.7 \mathrm{~s}$ & $\mathrm{COCH}_{3}$ \\
\hline$\underline{\mathrm{CH}}_{3}-\mathrm{CO}$ & $1.87(\mathrm{~s})$ & $24.3 \mathrm{q}$ & - \\
\hline
\end{tabular}

a,b, Spectra in DMSO-d . Assignments were made with the aid of the DEPT and 2D-shift-correlated HMQC and ${ }^{1} \mathrm{H}-{ }^{1} \mathrm{H}$ COSY spectral data. Chemical shift in $\delta$, multiplicities and coupling constants $(J)$ are in parentheses. Spectra were recorded at $500 \mathrm{MHz}$ for ${ }^{1} \mathrm{H}$ and $125 \mathrm{MHz}$ for ${ }^{13} \mathrm{C}$.

\section{Results and Discussion}

The bioactive soluble EtOAc part of a $\mathrm{CH}_{2} \mathrm{Cl}_{2}: \mathrm{MeOH}$ (2:1, v/v) extract, prepared from the leaves of C. braquiata, was chromatographed over Sephadex LH-20 column and preparative TLC to afford a new flavonoid $\mathbf{1}$, along with the know compounds apigenin (2), ${ }^{6}$ 7-O-methoxyquercetrin (3), ${ }^{7}$ quercetrin (4), ${ }^{8} \alpha$-amirin, $\beta$-amirin, ursolic and oleanolic acids. ${ }^{9}$ 
Compound $\mathbf{1}$ was isolated as a white amorphous powder, with molecular formula $\mathrm{C}_{30} \mathrm{H}_{34} \mathrm{O}_{15}$ deduced from the $[\mathrm{M}+\mathrm{Na}]^{+}$peak at $m / z, 657$ in the ES-MS and supported by ${ }^{13} \mathrm{C}$ and ${ }^{1} \mathrm{H}$ NMR data. Its UV spectrum exhibited characteristic absorbance bands of flavonols ${ }^{10}$ at 259 and $341 \mathrm{~nm}$. The ${ }^{1} \mathrm{H}$ and ${ }^{13} \mathrm{C}$ NMR spectra (Table 1) revealed two set signals, which features indicated a flavonoid with glycosidic and acetyl groups. The ${ }^{1} \mathrm{H}$ NMR signals attributed to the aglycone at $d 7.75(2 \mathrm{H}, \mathrm{d}, J 8.0 \mathrm{~Hz}), 6.89$ $(2 \mathrm{H}, \mathrm{d}, J 8.0 \mathrm{~Hz})$, identified as a $2 \mathrm{HAA}^{\prime}$ and a $2 \mathrm{H} \mathrm{XX}$ 'system, $6.63(1 \mathrm{H}, \mathrm{d}, J 1.25 \mathrm{~Hz}), 6.32(1 \mathrm{H}, \mathrm{d}, J 1.25 \mathrm{~Hz})$ showed characteristic pattern of kaempferol. ${ }^{5}$ The ${ }^{1} \mathrm{H}$ NMR spectra also showed signals at $\delta 5.30(2 \mathrm{H}$, br s), $3.92(2 \mathrm{H}, \mathrm{br}, \mathrm{dd}, J$ 9.0, $11.0 \mathrm{~Hz}), 3.48$ (2H, dd, J 9.0, $10.8 \mathrm{~Hz}), 3.28$ (2H, m), $3.08(2 \mathrm{H}, \mathrm{m})$ and $0.87(6 \mathrm{H}, \mathrm{d}, J 6.5 \mathrm{~Hz})$, which revealed the presence of at least two glycosyl moieties, clearly evidenced by integration area of the peaks corresponding to these signal values. In addition, a methoxyl and an acetyl groups were also confirmed by two singlets at $\delta$ $3.79(56.0 \mathrm{q})$ and $\delta 1.87(24.3 \mathrm{q})$ and 174.7 (s), respectively. The identification of the sugar moieties as two $\alpha$-rhamnopyranosides was determined from the chemical shifts, multiplicity of the signals, and absolute values of the coupling constants in the ${ }^{1} \mathrm{H}$ NMR and ${ }^{1} \mathrm{H}-{ }^{1} \mathrm{H}$ COSY spectra as well as ${ }^{13} \mathrm{C}$ NMR data. The signals observed in the ${ }^{13} \mathrm{C}$ NMR spectrum (Table 1) at $\delta 101.8(\mathrm{~d}), 74.4$ (d), 72.6 (d), 72.5 (d), 71.1 (d), 18.5 and 17.5 (q) clearly indicated that the sugar moiety was rhamnose. In addition, the evidence of two distinct signals for characteristic methyl groups of rhamnose deeply aided the proposal of two rhamnose moieties in compound 1. The ES-MS ions peaks at $m / z 365[\mathrm{M}-(2 \mathrm{x} \text { rham })+\mathrm{Na}]^{+}, m / z 363[\mathrm{M}-(294)+$ $\mathrm{Na}^{+}$and $m / z, 186\left[\mathrm{C}_{6} \mathrm{H}_{11} \mathrm{O}_{4}+\mathrm{Na}\right]^{+}$also emphasized the presence of two rhamnopyranoside units in compound $\mathbf{1}$. The first indication of the positions C-3 and C-5 as substitution sites in $\mathbf{1}$ was evidenced from the ${ }^{1} \mathrm{H}$ NMR spectrum, which do not showed the typical signals assigned to $\mathrm{H}-3$ and the HO-C-5 quelate. The HMBC spectrum (Table 1) confirmed these positions as glycosylation sites due to the connectivities that were observed between $\delta 5.30$ (1H, br s, H-1") and 134.2 (C-3) and the correlation between $\delta 5.30(1 \mathrm{H}$, br s, H-1"') and 161.7 (C-5). The correlation between the signal corresponding to $-\mathrm{OCH}_{3}$ at $\delta 3.79$ with $\mathrm{C}-4$ ' at $d 161.7$ also was important to attribute all substitutions in $\mathbf{1}$, if we consider that the only remain place linkage for the acetyl group should be at hydroxyl group in C-7. In fact, by the NOESY experiments (Figure 1) was observed a weak spatial correlation between the signal at $\delta 6.89$ (H-3' and/or H-5' with the resonance at $\delta 3.79$ corresponding to -OMe. The absence of cross peaks correlation between H-6 and H-8 with the $\mathrm{CO}$ of the acetyl group could suggested that this group was not attached to the hydroxyl at C-7. However, a correlation observed in the HMBC spectrum (Table 1) between the anomeric hydrogens at $\delta 5.30$ and C-5 (161.7) and C-3 (134.2) indicated that the second sugar unit was located at $\mathrm{C}-3$, and thus corroborated the acetylation site at $\mathrm{C}-7$. These findings confirmed the substitution pattern for compound $\mathbf{1}$. The absence of a bathochromic shift in the UV (methanol) spectrum after the addition of $\mathrm{AlCl}_{3}$ was other important evidence for the substitution of the 5$\mathrm{OH}$, as well as the substitution at $\mathrm{C}-7$ being indicated by the absence of a bathochromic shift in band II (ring A) upon addition of NaOAc. To our knowledge, $\mathbf{1}$ is a new flavonol derivative assigned as 4'-methoxykaempferol-7(acetyloxy)-3,5-O- $\alpha$-L-rhamnoside (1).

The strong antifungal activity detected in the crude extract (minimum amount required for the inhibition of fungal growth on TLC plates $=10 \mu \mathrm{g}$ for $C$. cladosporioides, standard nystatin $=1.0 \mu \mathrm{g}$ ) was decreased proportionally during fractionation procedures. The detection limit values of the $\mathrm{CHCl}_{3}$, and EtOAc bioactive solubles (50 and $30 \mu \mathrm{g}$, respectively) suggested that the antifungal activity was substantially lost during guidedfractionating of the EtOAc extract with fungus $C$. cladosporioides. The very weak activity detected for pure flavonols 1-4 (detection limit values higher than $300 \mu \mathrm{g}$ ) indicated that their individual activities are not potent enough to be considered for practical use or to justify the strong activity detected in the crude extract. The antifungal activity against $C$. cladosporioides was significantly enhanced when a combination of the flavonols 1, 2, 3 and $\mathbf{4}$ where tested. The detection limit of compound $\mathbf{1}$ against C. cladosporioides was reduced from 350 to $100 \mu \mathrm{g}$ when it was combined with compounds 2 (300), 3 (400), and 4 (250). Based on these observations, the synergistic activity of these compounds, and probably of others not isolated in this study, against this fungus, could be inferred.

\section{Acknowledgments}

This work was funded by grants from Biota-FAPESP and CNPq. A. C. de Oliveira thanks CAPES for providing a scholarship. V. da S. Bolzani and M. C. M. Young also are grateful to $\mathrm{CNPq}$ for the fellowships of scientific productivity. We thank Dr. J. M. David (UFBA) for facilities in the provision of plant material.

\section{References}

1. El-Hafiz, M.A.; Weniger, B.; Quirion, J.C.; Anton, R.; Phytochemistry 1991, 30, 2029. 
2. Bolzani, V.S.; Young, M.C.M.; Izumisawa, C.M.; Trevisan, L.M.V.; J. Braz. Chem. Soc. 1996, 7, 157.

3. Bolzani, V.S.; Young, M.C.M.; Furlan, M.; Cavalheiro, A.J.; Araújo, A.R.; Silva, D.H.S., Lopes, M.N.; Recent Res. Devel. Phytochem. 2001, 5, 19.

4. Carbonezi, C.A.; Martins, D.; Young, M.C.M.; Lopes, M.N.; Furlan, M.; Rodrigues Filho, E.; Bolzani, V.S.; Phytochemistry 1999, 51, 781.

5. Homans, A.L.; Fuchs A.; J. Chromatogr. 1970, 51, 327.

6. Wagner, H.; Chari, V.M.; Sonnenbichler, J.; Tetrahedron Lett. 1976, 21, 1799.
7. Shen, Z.; Theander, O.; Phytochemistry 1985, 24, 155.

8. Markham, K.R.; Ternai, B.; Stanley, R.; Geiger, H.; Mabry, T.J.; Tetrahedron 1978, 34, 1389.

9. Mahato, S.B.; Kundu, A.P.; Phytochemistry 1994, 37, 1517.

10. Markham, K.R.; Techniques of Flavonoid Identification, Academic Press: Tokyo, 1982.

Received: October 28, 2003 Published on the web: May 17, 2004

FAPESP helped in meeting the publication costs of this article. 